Running heads:

Recto: Haketia in Morocco

Verso: Yvette Bürki

\title{
Haketia in Morocco. Or, the story of the decline of an idiom
} Yvette Bürki

Yvette Bürki: University of Bern, Switzerland. E-mail: yvette.buerki@ rom.unibe.ch

\begin{abstract}
This contribution takes a diachronic look at the political, social, cultural and economic reasons behind the decline of Haketia, which has become one of the most symbolic icons in the collective memory of the Hispano-Moroccan Sephardic Jews in their new settlements. The article has three parts: it opens with a general section that introduces the concept of Sephardic Jew and sets out the linguistic varieties of this ethnic group; a second section contextualises the sociocultural and linguistic history of Sephardic Jews in Morocco after their expulsion from the Iberian Peninsula and up until 1860, the year of the Spanish military foray into North Morocco; and a third and central section examines the causes of the decline of Haketia and the current situation. The article concludes with glottopolitical reflections on the evolution of this idiom, the tension between a colonised and a colonising tongues, and the role of language in ethnic-cultural identity, all of which prove how linguistic homogeneity and linguistic difference can be considered the result of ideological expressions in the social and political processes of a given region.
\end{abstract}

Keywords: Sephardic Jews, Morocco, Haketia, glottopolitics

\section{Introduction}


In 1926 the first descriptive study of Haketia ${ }^{1}$ written by Benoliel opened with the following words:

Este dialecto, peculiar de los Judíos de origen ibérico establecidos en Marruecos desde la expulsión de España, y considerablemente distinto del que aún es hablado por los Judíos de Oriente, es un compuesto de castellano antiguo, más o menos bien conservado, de árabe, de hebreo, etc. a que se da vulgarmente el nombre de Hakitía.

[This dialect, peculiar to the Jews of Iberian origin who had settled in Morocco after being expelled from Spain, and considerably different to the one still spoken by the Jews in the East, is a mishmash of Old Spanish, more or less preserved, Arabic, Hebrew, etc., commonly known as Hakitía.]

(Benoliel 1926: 209)

Nineteen years later, Bénichou referred to Haketia as follows:

El estudio del judeo-español de Marruecos es además difícil en nuestros tiempos porque el dialecto ha estado sometido, desde hace varias generaciones, al influjo del castellano moderno, que lo ha invadido, destruyendo en él varios caracteres esenciales [...].

[The study of Moroccan Judeo Spanish is complicated in our time by the fact that the dialect has been exposed, over a few generations, to the influence of Modern Spanish, which has pervaded it, and has obliterated a number of its essential features (...).]

(Bénichou 1945: 209)

Finally, in 2008 Garzón defined the language of Moroccan Sephardic Jews as follows:

La jaquetía fue el dialecto que los judíos ibéricos establecidos en Marruecos después de la expulsión de España y que pasaron a residir en el Norte del país conservaron como lengua para comunicarse en el interior del grupo.

[Haketia was the dialect that the Iberian Jews who settled in Morocco after being expelled from Spain and who moved to the north of the country preserved as a language to communicate among themselves within the group.]

(Garzón 2008: 235)

If in 1926 Benoliel uses the present tense to speak of the Western Judeo-Spanish (Haketia), despite indicating that the other Eastern variety is still spoken by Levantine Sephardic Jews, as early as 1945 Bénichou warned of the erosion to which the language has been exposed due to the influence of Spanish. Most forceful was the tense chosen by Garzón in 2008 to define the condition of Haketia as a vehicle of communication: the past simple, "Haketia was ..."

This contribution will analyse from a diachronic perspective the political, social, cultural and economic reasons that led to the decline of Haketia, which today is one of the most emblematic icons used to recreate the collective memory of the Hispano-Moroccan Sephardic

\footnotetext{
${ }^{1}$ The glottonym has different graphic representations: haketía or hakitia, haketia, haquetia, jaquetia, etc. In this contribution we shall always use Haketia.
} 
Jews in their new settlements. The article is divided into three parts: a first general section that introduces the concept of Sephardic Jew and explains the linguistic varieties of this ethnic group (Section 2); a second part that contextualises the sociocultural and linguistic history of Sephardic Jews in Morocco following their expulsion from the Iberian Peninsula up until 1860, the year of the Spanish military incursion in north Morocco (Sections 3 and 4); a central part, that deals with the causes of the decline of Haketia and the present situation. The article concludes with glottopolitical reflections on the evolution of this idiom, the tension between a colonised and a colonising tongue, and the role played by language in ethnic-cultural identity that exemplify how linguistic homogeneity and linguistic difference can be understood as the result of the ideological expressions in a region's social and political processes (Irvine and Gal 2000).

\section{Basic concepts}

In diatopic terms, Haketia or Hakitia, a name given to this linguistic modality by its speakers, can be considered the variety of Judeo-Spanish spoken by the Sephardic Jews of North Africa. Specialists refer to it as Western Judeo-Spanish. ${ }^{2}$ The other main variety, Eastern JudeoSpanish, developed in the Sephardic Jewish communities of the Eastern Mediterranean basin, in the territories of the ancient Ottoman Empire and was known among its speakers as Judezmo. ${ }^{3}$

The term Sephardim is derived from the toponym Sepharad that since the 17th century has designated the Iberian Peninsula in the Jewish tradition. In this sense, Sephardim designates the Jews in the Iberian Peninsula (both in Spain and in Portugal) and their culture, which explains why it is used in opposition to Ashkenazi, a term employed to denote the French, German and Slavic cultural branches of Judaism. In its strictest sense, Sephardim is used in reference to the Jews who descended from those who had been expelled from the Iberian Peninsula and to those who, in the new territories of the diaspora, were culturally assimilated to them. This was the case of the Jews native of northern Morocco, who were culturally assimilated to the new immigrant Jewish group, the Sephardic Jews (cf. Section 3) and that of the Romaniote Jews assimilated to the Sephardic group in the Ottoman Empire. So, on the one

\footnotetext{
${ }^{2}$ Among the first studies of Haketia we should mention those by Meneu (1890), Benchimol (1901), the broad survey by Benoliel published in instalments between 1926 and 1952 in the Boletín de la Real Academia de la Lengua Española and reprinted in one volume in 1977 and in the one by Wagner (1931).

${ }^{3}$ Other names given to Eastern Judeo-Spanish by its speakers are spañolit, $\hat{j} u d i o ́$ and jidió. Today, in Israel Judeo-Spanish is called ladino (Bunis 1993: 414).
} 
hand it indicates the ethnic origin of the peninsular Jews, and on the other their diasporic condition as opposed to the Jews who were living in the Peninsula before the expulsion (Bürki et al. 2006: 7-8).

From a linguistic point of view, both varieties of Judeo-Spanish are commonly based on mediaeval Castilian that travelled with the Sephardic Jews after the expulsion of 1492. Outside of the Iberian Peninsula and due to the lack of normative pressure (García Moreno 2004: $365)$, it developed along different paths enabled by the system ${ }^{4}$ and preserved many of the forms that standard Spanish subsequently rejected. ${ }^{5}$ Secondly, these linguistic modalities have certain lexical particularities among which stand out Hebraisms and Arabisms, especially in the field of Jewish culture and religion, already in use before the expulsion. Thirdly, as in the general case of Jewish languages, both varieties employ Hebrew characters in the writing of their texts. Fourthly, the linguistic loans from the languages of the new surroundings of the Sephardic Jews who left the Peninsula. While there are a number of regional distinctions between Eastern varieties and those of North Africa at all levels of the system (Bunis 1993: 435436; Bunis 2008), the biggest difference lies precisely in the origin of the inclusions of words from neighbouring languages, for while Judezmo initially ${ }^{6}$ adopted (chiefly lexical) elements from Turkish and other sources (Slavic languages, Italian, Romanian and Modern Greek), Haketia took Arabisms and Berberisms (Wagner 1931; Martínez Ruiz 1992; Bunis 1993; Bunis 2008).

In spite of the linguistic parallels, ${ }^{7}$ Judezmo and Haketia followed different paths determined by political, social and geographic factors, although the end result was the same - the disappearance of both varieties, as Judeo-Spanish has ceased to be used as a vehicular language in general oral and written communication by both Eastern and North African Sephardic Jews. We shall now focus on Western Judeo-Spanish or Haketia, and shall only refer to Eastern Judeo-Spanish or Judezmo in passing and in comparison with Haketia.

\footnotetext{
${ }^{4}$ Among the elements of mediaeval Castilian preserved in Judeo-Spanish are the two voiceless and voiced sibilants $/ \mathrm{s} / \mathrm{y} / \mathrm{z} /$ and the voiceless and voiced prepalatals $/ \mathrm{J} / / 3 /$. Moreover, Judeo-Spanish is yeista and seseante, in other words it has only one palatal phoneme, the central $/ \mathrm{j} /$ instead of the lateral $/ \lambda /$ and the central $/ \mathrm{j} /$ and no interdental $/ \theta /$. Due to the lack of normative pressure, present characteristics of Eastern Judeo-Spanish include the alternation of the mediaeval sequence [fwe] and [xwe], whereas in Western Judeo-Spanish the diphthong is reduced to [fe] (Bunis 1993: 435).

${ }^{5}$ Examples are the Hebraism šabbat as opposed to sábado 'Saturday' and the Arabism alhad as opposed to domingo 'Sunday'.

${ }^{6}$ At a second stage, the Eastern variety underwent a process re-Romanisation based chiefly on French; to a lesser degree and according the area, based on Italian and Spanish. This modern variety of Eastern Judeo-Spanish is known as neo-Judeo-Spanish (cf. Schmid 2008).

${ }^{7}$ On the linguistic parallels between Eastern and Western Judeo-Spanish cf. Bunis (1993) and Aslanov (2008).
} 


\section{Settlements and demography ${ }^{8}$}

While it is undeniable that the relations between the autochthonous Maghrebi Jews and the Spanish Jews were uninterrupted, the migrations of Sephardic Jews to the Maghreb began in the 13th century, when a group of Jews from Minorca moved to the central region of the Maghreb in 1287. In the late 14th century and as a result of the pogroms of 1391, the destination chosen by most Spanish Jews was Algeria; after their expulsion from the Iberian Peninsula (from Spain in 1492 and from Portugal in 1496), those Sephardic Jews who crossed the strait settled chiefly in Morocco. According to Garzón (2008: 41-45), there were four significant migratory waves to Morocco between 1492 and 1498, yet in comparison with the Sephardic Jews who moved to the Ottoman Empire, the number who settled in Morocco was relatively small. Furthermore, as a result of the serious difficulties they faced in these territoriespolitical chaos and constant fighting between different groups and local dynasties, not to mention the extreme poverty of living conditions - many of them would not remain in Moroccan lands.

The first settlements were Oran, Algiers and Fez, from where the vast majority moved to coastal cities in northern Morocco: Tetouan, known as Yerušaláyim chiquita 'small Jerusalem' (Benarroch 1970: 266), Tangiers, Ceuta, Alcazarquivir, Larache, Mecilla and Arcila. A few others settled inland, in Mequínez for instance, inhabited for centuries by Mahgrebi autochthonous Jews that spoke Berber-Shelja. As we see, two Jewish ethnic groups settled in Morocco, distinguished by their origin, language and different rites and customs. These differences between Sephardic and Mahgrebi were reflected in the names given to the different groups: the local Jews called the Sephardic Jews rumiyyin (Arabic for 'European') or megorashim (Hebrew for 'expelled'), while in their turn the Sephardic Jews referred to the toshavim (local community or 'autochthonous') as forasteros 'foreigners'. This name, that may at first seem paradoxical, derives from the fact that the Sephardic Jews considered other Jews foreign to their community. ${ }^{9}$ Furthermore, the community of autochthonous Jews who encountered the Sephardic Jews upon their arrival in the north of Morocco was relatively small. Over time, this led to the acculturation of the Mahgrebi Jews in northern Morocco, who adopted the liturgy and traditions of the Sephardic Jews.

\footnotetext{
${ }^{8}$ This section is based on Abitol (1993), Assis (2008), Ayoun (1993), Benady (1993), Benarroch (1970), Cohen (1985), Garzón (2008), Laskier and Basha (2003), Leibovici (1984) and Zafrani (1993).

${ }^{9}$ In this sense, cf. Calvet (2002 [1974]: 46-47) on how the names of tongues and ethnic groups reflect the category of others, of those foreign to the community.
} 
Descending towards the central and southern areas of Morocco, and travelling inland we come across a different situation, for there are a greater number of autochthonous and Arabophone Jewish communities which, in turn, also absorbed ancient Sephardic communities who lost their Spanish tongue and assimilated the vernacular Arabic of those communities. In short, up until 1860 we find in Morocco the following ethnocultural scenario as regards the Jewish population: autochthonous Arabophone Jews in the centre and south of the country, autochthonous Berber Jews in the inland northern area and Spanish-speaking Sephardic Jews in the coastal regions of the north.

\section{The linguistic situation up until 1860}

As throughout Dar-al-Islam (literally 'House of Islam', or 'Islamic territories'), Jews were dhimmi, the Arabic term imposed by the dominant religion on non-Muslims. Their payment of Jizya 'Islamic tax', regulated in the dhimma 'protection' contract, non-Muslim ethnic minorities were guaranteed a certain number of rights and, above all, were allowed a high degree of judicial, administrative and cultural autonomy. This fact helped Sephardic Jews to preserve their own language and ethnic religious symbols of identity (Benady 1993: 508; Zafrani 1993: 500). To this we should add that Moroccan Jews usually lived in Jewish quarters, the socalled mellahs, which in spatial terms also favoured intergroup cohesion. As was the case as well with the Sephardic Jews in the East, the intercommunity language was the reflection of the Spanish-European identity of the Sehardi Jews of Morocco (Cohen 1985: 246; Aslanov 2008: 217). In other words, as Hassán points out (1969: 2135), Haketia wasn’t just a means of expression; above all it was a symbol of Jewish identity among an Arab-speaking population. On the other hand, as Bentolila states (2008), the variety of Spanish among Moroccan Sephardic Jews depended on the style of text, even before the military occupation of 1860 and the establishment of the Protectorate in 1912 (cf. Section 5), which indicates that relations between Moroccan Sephardic Jews and Spain were not cut off completely in 1492 (Hassán 1965: 27; Bentolila 2008: 168). The greater the communicative distance of the text and the more it belongs to formal and religious registers, the smaller the presence of Arabisms ${ }^{10}$, and

\footnotetext{
${ }^{10}$ In this article we use the terms of language of immediacy (Ger. Sprache der Nähe) and language of distance (Ger. Sprache der Distanz) taken from the integrative communicative model provided by Koch and Oesterreicher $(1985,1994)$. As pointed out by Elspass (2012: 157) in relation to the model of German Romanists, "Verbal language is transmitted either by voice or by the written word, so the phonic and the graphic medium constitute a strict dichotomy. The linguistic conception of a text, however, can be established only relative to prototypical texts of 'immediacy' (orality, informality, unplannedness) and prototypical texts of 'distance' (literateness, formality, plannedness)". On the conceptual level, the texts are varied, and exemplify both communicative distance (i.e. legal contracts) and communicative proximity (i.e. colloquial conversations), following a series
} 
from the 18th century onwards Hispanicising features gradually gained ground, such as the use of the voiceless velar fricative / $\mathrm{x} /$ (represented in Al-Jamia by the $\langle$ '’ $>$ and $<\mathrm{n}>$ ) as opposed to the prepalatal / $/$ and /3/ (traditionally represented in Judeo-Spanish by $<$ ' $>$ and $\left\langle{ }^{\prime} \uparrow>\right) .{ }^{11}$ So it is not surprising, as we learn from Bentolila (2008: 169), that after 1860 and especially after 1912 the desire for a 'pure' tongue, i.e. the Spanish spoken in Spain at this time, should have experienced such an upsurge. We will agree, therefore, that Haketia is the vernacular used by Sephardic Jews as an intergroup vehicular language and that in the late 18th century it began to lose its 'Haketian' features and move towards more Hispanicised forms, as production gradually converge in the continuum of the language distance. ${ }^{12}$

A key problem in the diachronic study of Western Judeo-Spanish, however, is the fact that there is little written evidence of it until well into the 19th century, despite our knowledge of communal regulations such as the takkanot of Fez, written in 1494 and included, along with other subsequent regulations in Kerem ḥemer, by Abraham Ankawa (Liorno 1896, 1871), brief passages of rabbinical prose such as the Wayo'mer Yiẑhaq by Yiẑhạaq ben Walid, and several manuscripts (Bunis 1993: 405). Unlike Eastern Judeo-Spanish, there is no proof either of local production printed in the vernacular (Bunis 1993: 412). Studies of the Judeo-Spanish variety have been carried out from the 19th century onwards, starting chiefly from its rich oral literature, to which other sorts of texts such as communal and epistolary documents have been added. $^{13}$

As to Hebrew, it enjoyed the status of holy language for solemn and religious use, so knowledge of it depended on one's social rank (i.e. their standing as rabbis) and gender (as in traditional Sephardic society women usually had little access to Hebrew).

of parameters defining their authors, such as formality, spatial or temporal distance, private or public setting of the communication, familiarity of the interlocutor, spontaneity and free or fixed topics (cf. also Elspass 2012: 157).

${ }^{11}$ Bentolila (2008: 165, 167) quotes two documents in Haketia, written in Arabic characters of 1837, that contain these Hispanicising characteristics: a handwritten text that describes an event that took place in the city of Tetouan and a book addressed to women that provided instruction in their religious obligations. On the Hispanicising characteristics of texts in Haketia, cf. as well Bunis (1993: 427).

${ }^{12}$ On the concepts of language of immediacy and language of distance cf. Note 10.

${ }^{13}$ Such as the Libro de actas de la Junta selecta de la comunidad hebrea de Tanger desde heshvan 6621 hasta 29 iyar 5635 for instance, published by Sidney Pimienta and P. Abendsur in 1992 (quoted in Bentolila 2008: 167, note 105). For the linguistic study of oral sources, see the work by Pimienta (1993). Other documents such as letters, for instance, have been published in "El kantoniko de la haketia", a section devoted to Haketia in the review Aki Yerushalayim (http://www.aki-yerushalayim.co.il/ay/index.htm), published by the Sefarad association. 
On the other hand, with those who did not belong to the ethnic religious in-group, the Sephardic Jews spoke dialectal Arabic. ${ }^{14}$ In other words, and unlike what was happening in most of the Sephardic communities of the East where there was no true command of the neighbouring language, ${ }^{15}$ the Moroccan Sephardic Jews who spoke Haketia were bilingual. Thus Arabic was a homoglot space (Cohen 1985: 259) in the sense that it was linguistically shared between the Sephardic Jews and the Arabs. Furthermore, Arabic has left its mark on the phonology of Haketia, as illustrated by the presence of $h a$, graphically $\langle\pi\rangle$ in Haketia (e.g. hammal 'porter'), $x a,\langle\supset\rangle$ (e.g. xatar 'consideration'), ha, <ה> (e.g. huá 'air'), and ayn, <y> (e.g. ažmía, literally 'foreign language'), by the inclusion of Arabic loans and by the presence of geminated consonants in Spanish words, as for instance in Hak. aźźul, as opposed to Sp. azul and in Hak. corazzón, as opposed to Sp. corazón. ${ }^{16}$

In short, before 1860 among the Sephardic communities of northern Morocco we discover the languages shown in Table 1.

Table 1: Languages of the Sephardic communities in northern Morocco before 1860

\begin{tabular}{|lll|}
\hline \multicolumn{2}{|c|}{ Intercommunity languages } \\
\hline + Language of immediacy & + Language of distance \\
\hline + Haketia & & - Haketía features \\
& & + Hebrew \\
\hline Extracommunity language & \\
\hline Moroccan dialectal Arabic \\
\hline
\end{tabular}

\section{Haketia in the face of European influence after 1860}

\footnotetext{
${ }^{14}$ We shall not enter here into the problems of Judeo-Arabic, which are beyond the scope of this article.

${ }^{15}$ There is a huge bibliography on the limited command of neighbouring languages among the Sephardic communities of the East. To establish a comparison with the situation of the Jews in Morocco, cf. Bunis (2008: 183).

${ }^{16}$ These examples are from Bunis (2008: 186). For more examples of the influence of Arabic on the phonology of Haketia cf. Bunis (2008: 186-188).
} 
As is well known, throughout the 19th century European countries extended their colonialist ambitions towards North Africa. France and Spain in particular turned their expansionist gaze to the Maghreb.

In the case of Spain, in 1859 Spanish General Leopoldo O'Donnell, who two years before had commanded a military coup (1856) with the support of France and Great Britain, occupied Tetouan and declared war on Morocco, taking as a pretext the incursions of Moroccan armed groups from the Rif region into the Spanish enclaves of Ceuta and Melilla. After this first Spanish-Moroccan war (1859-1860), Spain set up a colonial administration in Tetouan that would last until 1862. Since then, the presence of Spain in northern Morocco would be continuous. Finally, adducing the unceasing regional conflicts in Morocco, years later, the signing of the Treaty of Fez in March 1912 made the French protectorate of most of Morocco official. In November of that same year the Spanish protectorate was declared in the north, which comprised the cities of Tetouan, Larache, Alcazarquivir, Arsila, Xauen, Nador and the mountainous areas of the Rif. The establishment of the Spanish protectorate didn't stop the revolts against the colonial administration in the Rif area, unleashing instead a series of wars known as the Wars of Africa or War of the Rif.

Moreover, on 18 December 1923 the defining Convention regarding the Organisation of the Statute of the Tangier Zone was signed, by means of which Tangiers was granted its status as an international zone under the joint administration of European states. This lasted until Spain's annexation of the city between 1940 and 1945. With the independence of Morocco in 1956, Spain didn't leave the Maghreb completely. A part of Ifni remained under Spanish control until 1958 (López García 2013: 69); the other part remained under control of the Spanish authorities until 1968, and Western Sahara Occidental even until 1975. In 1956 Tangiers was definitively reinstated as a city in the Kingdom of Morocco.

\subsection{Spanish}

As we see, Spain's presence in northern Morocco lasted over 40 years. During this period Spanish became the official language of the administration, the language of the colonial authorities and therefore a language of prestige among the Sephardic Jewish community. Furthermore, for a variety of reasons, as from 1860 onwards several migratory waves of Spanish citizens, especially Andalusian (López García 2012: 2-11) arrived in this Mahgrebi area, chiefly in Tangiers and to a lesser extent in Tetouan, which naturally resulted in the continuous presence of Spanish. Table 2 shows this uninterrupted existence of Spanish emigrants in 
Morocco from 1891 to 1908 , that is, even before the onset of the Spanish protectorate in the north.

Table 2: Spanish emigration to Morocco (1891-1908) ${ }^{*}$

\begin{tabular}{|c|c|c|c|}
\hline Year & Entrance & Exit & Migratory Balance \\
\hline 1891 & 1,755 & 1,393 & 362 \\
\hline 1892 & 1,887 & 1,386 & 501 \\
\hline 1893 & 1,478 & 1,207 & 271 \\
\hline 1894 & 1,542 & 1,229 & 313 \\
\hline 1895 & 1,171 & 845 & 326 \\
\hline 1896 & 1,490 & 1,133 & 357 \\
\hline 1897 & 1,510 & 1,215 & 295 \\
\hline 1898 & 1,152 & 1,046 & 106 \\
\hline 1899 & 1,302 & 1,144 & 157 \\
\hline 1900 & 1,451 & 1,036 & 415 \\
\hline 1901 & 1,981 & 1,471 & 510 \\
\hline 1902 & 2,004 & 1,788 & 216 \\
\hline 1903 & 2,046 & 1,845 & 201 \\
\hline 1904 & 2,138 & 1,881 & 257 \\
\hline 1905 & 2,806 & 2,097 & 709 \\
\hline 1906 & 2,991 & 2,530 & 461 \\
\hline 1907 & 5,950 & 4,068 & 1,882 \\
\hline 1908 & 3,681 & 2,927 & 754 \\
\hline Totals & 38,334 & 30,241 & 8,093 \\
\hline
\end{tabular}

* Source: Instituto Geográfico y Estadístico de la Emigración y la Inmigración de España. Quoted by Vilar: (2012: 247).

On the other hand, in the late 19th century and first quarter of the 20th century the Jewish population experienced heavy internal migration which led to them to concentrate in northern coastal cities (Garzón 2008: 170-171) and to resettle in Gibraltar, Ceuta and Melilla. Table 3 gives the figures of Sephardic Jews inhabiting the protectorate territories for the years 1913 and 1920, according to Garzón (2008: 171), that reveal the increase in numbers in coastal towns. 


\begin{tabular}{|l|c|c|}
\hline \multicolumn{1}{|c|}{ City } & $\mathbf{1 9 1 3}$ & $\mathbf{1 9 2 0}$ \\
\hline Tetouan & 4,250 & 5,000 \\
\hline Larache & 2,199 & 3,000 \\
\hline Alcazarquivir & 1,624 & 3,000 \\
\hline Arcila & 442 & 1,500 \\
\hline
\end{tabular}

The increase in numbers of Sephardic Jews is clear in Larache, the city where the Spanish protectorate first came into being (Garzón 2008: 167), in Alcazarquivir and in Arcila, although the information regarding the latter is called into question by Garzón himself (2008: 178). As to Spanish cities and to Tangiers, the data Garzón provides (2008: 172) for the same years, 1912 and 1913, are shown in Table 4.

Table 4: Number of Sephardic inhabitants in other cities in northern Morocco

\begin{tabular}{|l|c|c|}
\hline \multicolumn{1}{|c|}{ City } & $\mathbf{1 9 1 3}$ & $\mathbf{1 9 2 0}$ \\
\hline Melilla & 3,290 & 3,000 \\
\hline Tangiers & 12,000 & 18,500 \\
\hline Ceuta & - & 2,500 \\
\hline
\end{tabular}

As we see, the figures for Tangiers leave no doubt as to the importance of this city as the place of residence par excellence of the Sephardic Jews.

With respect to the linguistic situation, as Cohen states in a letter of 1903 addressed to the Alliance Israélite Universelle (AIU) authorities in Tangiers, for instance, in the early 20th century most of the inhabitants still spoke Haketia, which he described as "a form of corrupted Spanish”, although some already used Spanish as a language of communication:

The language spoken locally is a form of corrupted Spanish. It is a veritable amalgam, in which Spanish is predominant; but to this Judeo-Spanish tongue have been added Hispanized Arabic words; verbs and expressions borrowed from Arabic and Hebrew complete the bizarre mixture. This language is even more corrupted among the immigrants from the interior, who have already begun to assimilate to their fellow Jews here. Their accent is deplorable and they pronounce certain letters differently. One could posit with a high degree of certainty that the Judeo-Hispanic-Arabic language is spoken by more than twothirds of the entire community. Those who know a relatively pure Spanish use it naturally in conversation, resorting to the other language when dealing with others who would not understand them were they speak correctly [...]. (Y. Cohen, Tangiers, 1903, Archives of the AIU, Tunisia 1.D.1, quoted in English by Rodrigue [2003: 127-128]) 
The official Spanish presence and the influence of the language were translated into the extinction of Haketia. Among the reasons for its disappearance as a vehicular language we could mention those related to a Spanish identity shared with the new colonial authorities, linguistic ideology, education and socio-economics, as we will see in the following sections.

\subsubsection{The identity bond}

Even before the protectorate, during the occupation, Sephardic Jews had shown a fraternal spirit to the Spanish. Pedro Antonio de Alarcón, the journalist who in 1860 had published his Diario de un testigo de la Guerra de África describing his personal vision of the capture of Tetouan by General O'Donnell, relates his encounter with Sephardic Jews as follows: ${ }^{17}$

Empezaron a aparecersenos algunas flacas y pálidas mujeres o endebles y afeminados mancebos vestidos con trajes e vivos colores. Eran judíos, hallábanse apostados a los huecos de las puertas de las esquinas para saludarnos:

¡Bienvenidos! ¡Bienvenidos! ¡Viva la Reina de España! ¡Vivan los señores! Gritaban en castellano aquellas gentes - pero con un acento particular enteramente distinto al de todas nuestras provincias.

[A few lean and pale women and weak and effeminate youths dressed in suits and bright colours appeared before us. They were Jews, and stood in door frames on corners to greet us:

Welcome! Welcome! Long live the Queen of Spain! Long live the masters! They shouted in Castilianthough with a peculiar accent that was completely different to those of all of our provinces.]

(Alarcón 1860: 115)

In their turn, Leibovici (1984) and González García (1987) gather much information that proves the kinship the Sephardic Jews felt for the Spanish invaders. According to Leibovici (1984), this was when their emotional ties with Spain were strengthened.

The passage in the letter that the Tangerine of Sephardic descent Pinhas Asayag ${ }^{18}$ sent to Senator Ángel Pulido Fernández ${ }^{19}$ on 11 July 1904 and which the latter reproduces in his

\footnotetext{
${ }^{17}$ During the occupation, the Spanish consuls in Tetouan also protected the Jews against the Arabs, even though there were no official Spanish guidelines on this issue (Leibovici 1984: 62-64; González García 1987: 17).

${ }^{18}$ The Sephardic author Pinhas Asayag was an outstanding journalist and man of letters who lived in Tangiers in the last third of the 19th century and first decades of the 20th century. Close to Ángel Pulido, he supported the latter's campaign (cf. Díaz-Más 2013: 141: note 47; Garzón 2008: 436).

${ }^{19}$ Senator Ángel Pulido Hernández, a doctor by profession, fought tenaciously to renew the ties between Spain and the Jews of Spanish descent expelled in the 15th century. A liberal thinker, he published several books in defence of Sephardic Jews, among which mention should be made of Españoles sin patria y la raza sefardi
} 


\title{
book Españoles sin patria y la raza sefardi (1905) highlights these feelings of fraternity felt
}

\author{
by at least part of the population of Moroccan Sephardic Jews:
}

\begin{abstract}
Aunque ya tuve el gusto de manifestar a Vd. oportunamente, la gratitud de todos nosotros hacia $\mathrm{Vd}$. por sus simpatías á la raza israelita, su propaganda de confraternidad entre dos pueblos hermanos y su nobilísima campaña en favor del mejoramiento y difusión del habla hispana entre los judíos de Oriente y Occidente, quiero en esta ocasión, lo mismo en mi nombre que en el de los israelitas de Tánger, hacer público, por medio de la prensa, el testimonio de nuestro agradecimiento hacia el campeón esforzado que con tanta gentileza de espíritu, como gallardía y resolución, se lanza á la palestra en pro de un noble ideal, que hace honor á Vd. y á la misma España, de cuyos altos intereses y prestigios se muestra Vd. denodado adalid. Aquí seguimos paso á paso y con el mayor interés, su campaña en la prensa española; aplaudimos con vivo entusiasmo sus grandes iniciativas y loables esfuerzos y hacemos votos por que el éxito corone su obra redentora, ya que con un valor y constancia que despiertan nuestra admiración, se afana $\mathrm{Vd}$. porque España conozca y se atraiga á un gran número de sus antiguos hijos, todos corazones rendidos, que quieren con singular afecto á la que consideran su madre y ha sido cuna de sus gloriosos antepasados. Celebramos con la mayor efusión y nos consideramos halagados al poder apreciar los hermosos resultados de su infatigable propaganda, pues por de pronto ya ha conseguido $\mathrm{Vd}$. hacer opinión en España, al descubrirles un mundo nuevo que es todo español, atrayéndose á la vez elementos de valía, cuyo concurso ha de contribuir á facilitar la magna obra de $\mathrm{Vd}$. [...]. El que estas líneas tiene el honor de dirigirle, así como los israelitas de Tánger felicitan á Vd. y hacen estensivo su agradecimiento á la Real Academia Española, á la Sociedad de Escritores y Artistas, á su digno Presidente el Sr. Echegaray, á los escritores, publicistas, periódicos y á cuantos se adhieren á la causa que Vd. sostiene y toman en ella una parte activa, probándonos de este modo que no son indiferentes á las ardientes simpatías y cariño sincero que los israelitas de origen español sentimos por la hidalga patria del Cid [...]. En su empresa le acompañamos con el corazón y el pensamiento. Adelante y Viva España!
\end{abstract}

[Although I have already had the pleasure of opportunely expressing to you the gratitude we all feel for you on account of your affection towards the Israeli race, your promotion of fraternity between two united peoples and your noble campaign in favour of the improvement and diffusion of the Spanish tongue among the Jews of East and West, in my name and in those of the Israelites of Tangiers I should now like to make public, through the press, the testimony of our appreciation of the zealous warrior who, with a gentle spirit, courage and determination, fought for a noble ideal, that honours you and Spain itself, of whose righteous interests and prestige you have proven to be a brave champion. Here we follow, step by step and with the greatest interest, your campaign in the Spanish press; we applaud with eager enthusiasm your great initiatives and praiseworthy efforts, and hope that success will crown your redeeming task, as with a courage and perseverance that rekindle our admiration, your efforts are aimed at achieving that Spain meets and attracts a large number of her former sons, all of them surrendered hearts who are markedly fond of what they consider their mother country, the cradle of their glorious ancestors. We honour with the utmost effusiveness and are pleased to be able to appreciate the beautiful results of your indefatigable propaganda, for you have already succeeded in creating an opinion in Spain by revealing to them a new world that is totally Spanish, while attracting valuable elements whose concurrence should help favour your great task. (...) He who has the honour to write you these lines and the Israelites of Tangiers congratulates you and extends his gratitude to the Royal Spanish Academy, the Society of Writers and Artists, its respectable President Sr. Echegaray, the writers, publicists, newspapers and all those who support the cause you uphold and play an active part in it, thus proving to us that they are not indifferent to the passionate affection and sincere fondness that the Israelites of Spanish descent feel for the noble homeland of El Cid. (...) Our hearts and thoughts accompany you in your venture. Forward and Hail Spain!]

(Quoted in Pulido 1905: 80-81)

(Madrid, 1905). On Pulido's relationship with Sephardic Jews from North Africa, cf. Meyuhas Ginio [2008: 111$126]$. 
In this letter, written, by the way, in perfect Spanish, Sephardic Jew Pinhas Asayag thanks Senator Ángel Pulido for the campaign he launched in the Spanish press and political circles in favour of Sephardic Jews, championing their re-Hispanicisation. Pinhas Asayag refers to the Sephardic Jews as "ancient sons [of Spain]" who "regard the country [of Spain] as their mother" and thank him for his "redeeming task" that has made it possible for Spain to discover "a new world that is totally Spanish", i.e. that of the "Israelites of Spanish descent" who feel "passionate affection and sincere fondness [...] for the noble homeland of El Cid". This feeling must have contributed to the need for them to express themselves in the Spanish of Spain, "real Spanish".

The imposition of the Spanish protectorate in 1912 entailed political changes for the Sephardic Jews, given that their status as dhimmi, i.e. as foreign subjects who were tolerated because they paid the tax. A change was simultaneously produced in linguistic terms for Sephardic Haketia speakers, for it went from being the "other", alloglot language, not spoken by the Muslim majority to a state of homoglossia with respect to the language of the colonisers (Aslanov 2008: 212). ${ }^{20}$ From this point of view, the common linguistic basis provided by Haketia did not merely encourage communication between Moroccan and Spanish Sephardic Jews, but also favoured, at least among a group of them, an emotional and identity closeness that led them to reminisce on their common Spanish past.

\subsubsection{The language of civilisation and modernisation}

Another reason for this was the standing of Spanish as a modern and cultural language among the Jewish population in general. As before in 1492, when the Sephardic Jews arrived in Arab lands (cf. Section 3), Spanish was regarded as the language of civilisation. To quote Benchimol:

Aux yeux des Israélites indigenes, l'espagnol représente d'autres idées, d'autres mœurs, la civilisation en un mot. De là un secret désir de connaitre cette langue et de parler aussi bien que les Israélites du Nord (Benchimol 1901: 130)

[In the eyes of the native Israelites, Spanish stands for other ideas, other traditions and customs, in a word, civilisation. That's why a secret desire of the Israelites (of the interior) is to learn this language and speak it as well as the Israelites of the north (those of the coastal cities of the north).]

(Benchimol 1901: 130)

\footnotetext{
${ }^{20}$ For the concept of homoglossia as opposed to heteroglossia see Cohen (1985).
} 
The situation of Sephardic Jews during the Spanish protectorate improved considerably (González García 1986: 9), particularly that of the Jewish bourgeoisie that for many years made up the industrial and commercial ranks of the population in the different cities (Garzón 2008: 169). Parallel to this material progress, Haketia lost ground to re-Hispanicisation. "True" Spanish was, therefore, the language of civilisation, progress and the bourgeoisie.

In short, in the early 20th century the Sephardic bourgeoisie, in Tangiers and Tetouan at least, spoke Spanish, as revealed by the following passage in a letter Pinhas Asayag sent to Pulido on 9 June 1904:

No ya como obra de justicia, hasta por especulación, como interés patriótico, debieran los gobiernos españoles secundar los esfuerzos de Vd. y apoyar con todas sus fuerzas y los medios de que disponen, para poner en práctica el programa que con mano maestra, Vd. traza en su libro y acudir, lo antes posible, á salvar un tesoro que amenaza perderse, un rico edificio que se desmorona, un idioma que se estingue. $\mathrm{Y}$ no hablo ahora de Marruecos, porque aquí, en este país, aunque falten profesores de español, y en algunas ciudades del imperio no se hable con la pureza y corrección necesarias, no estamos en el caso de los israelitas de Oriente, cuyo amor inestinguible á España me conmueve, cuya jerga, patois, dialecto ó lo que sea, parece llamado á desaparecer, y esto no debe ser visto con indiferencia por cuanto se trata de un asunto de riqueza nacional. Manténgase entre los hebreos el castellano, en toda su plenitud; sosténgase en toda su pureza y con todas las dulzuras, sonoridades, gentilezas y donaires de un idioma tan rico como hermoso, y con el cual dicen mis correligionarios de Oriente que se habla al Dios de las Alturas, entonces España, no solo habrá estendido su soberanía intelectual, sino que conquistará una influencia internacional que sera la envidia de otras potencias.

[Not simply as a matter of justice, but as a question of deliberation and for patriotic interest, Spanish governments should second your efforts with all their strength and the means at their disposal, supporting and putting into practice the programme that you masterfully draw up in your book and, as soon as possible, coming to the rescue of a threatened treasure, a rich edifice that is crumbling, a language that is dying out. I'm not speaking now of Morocco-here, in this country, despite the shortage of Spanish teachers and the fact that in some cities of the empire the language isn't spoken with the necessary degree of accuracy and purity, the case is different to that of the Israelites of the East, whose inextinguishable love for Spain moves me, and whose jargon, patois, dialect or whatever seems destined to disappear, and this shouldn't be looked upon with indifference as it is a question of national richness. Let Castilian be preserved among Hebrews in its fullness; let it be supported in all its purity and with all the delights, sonorities, courtesies and graces of a language as rich as it is beautiful, a language that according to my brethren from the East is used to speak to the God of Heights, and then Spain will not only have extended her intellectual sovereignty but will attain an international influence that will be the envy of other powers.]

(Quoted in Pulido 1905: 164 -165)

In reference to Pulido's book published that same year of 1904, Intereses nacionales: los israelitas Españoles y el idioma castellano in which the senator explains the need to reHispanicise the Sephardic Jews of the East and those of Morocco not only as a moral undertaking but as an issue of national interest on account of the economic advantages it would entail, Asayag draws a comparison between the state of Spanish in the East and the West: in spite of the fact that there is a shortage of Spanish teachers in Morocco and that in some regions of Morocco the language isn't spoken with total accuracy, it cannot be compared to the situation of Spanish in the East, where a "jargon, patois or dialect" is spoken, which should consequently disappear in favour of correct Spanish. 


\subsubsection{Education}

Having reached this point we should ask how the Sephardic Jews learnt Spanish. As we see, if in the early 20th century senator Pulido was struggling to increase the teaching of Spanish both among the Sephardic communities of the Ottoman Empire and among those of North Africa, in his turn Asayag underlines the lack of teachers of Spanish. In other words, unlike what was happening with the teaching of French thanks to the schools of the AIU, in the eyes of Hispanophiles and in terms of institutionalised teaching, Spanish did not enjoy a strong presence among the Jews of Morocco, at least not between the late 19th century and the first quarter of the 20th century in the Protectorate's period. ${ }^{21}$ In chapter VII of his book Los hebreos en Marruecos: estudio histórico, político y social, author Manuel Ortega (1888-1943) precisely, ${ }^{22}$ a journalist who lived in Tangiers for many years, carries out a survey of the schools and the traditional education of Sephardic Jews, which was the only one that existed before European presence: ${ }^{23}$

La enseñanza israelita descansa sobre el Talmud. Las sellah o escuelas judías eran en Marruecos un remedo de las coránicas, y los estudiantes en los Talmud Thora imitaban a sus colegas musulmanes en el cántico monótono con que recitan las lecciones y en el rítmico balanceo del cuerpo con que acompañan el estudio.

[Israelite teaching rests on the Talmud. In Morocco, Selah or Jewish schools were a copy of Koranic schools, and students at the Talmud Thora imitated their Muslim colleagues by reciting their lessons in a monotonous chant and by the rhythmical swaying that accompanied their reading.]

(Ortega 1919: 264-265)

Ortega also praises the Spanish initiative of setting up the Alfonso XIII schools: ${ }^{24}$

En Alcazarquivir un español bizarro llamado D. Cristóbal Cala, fundó casí sin recursos las escuelas de Alfonso XIII, auxiliado por entonces Cónsul de España en Larache, D. Juan V. Zugasti y por D. Hugo Engerez. [...]

\footnotetext{
${ }^{21}$ On the situation of the Spanish language before the establishment of the protectorate, cf. Morgenthaler in this issue. Mention should also be made of the fact that during the period of the occupation, in 1886 permission was granted (although no financial support was officially provided) for the opening of two Spanish schools for Jews in Larache and in Tetouan (González García 1987: 16).

${ }^{22}$ Manuel Ortega Pichardo (1888-1943) was a journalist and founder of the Compañía Iberoamericana de Publicaciones, a publishing house financed by the representative of the Rothschilds in Spain, Ignacio Bauer. During his long sojourn in Tangiers he was very active as a journalist and publisher of several newspapers and magazines, among them the important newspaper El Heraldo de Marruecos (cf. Section 5.1.5). As Paloma DíazMás (2013: 138) observes, Ortega was a liberal thinker and a follower of Pulido. On Ortega's position regarding the Sephardic Jews of Morocco in contrast with other characters of the same period, see the interesting study by Díaz-Más (2013).

${ }^{23}$ On the different types of traditional school in northern Morocco see Simon (2003: 142-164) and Laskier and Bashan (2003: 483-484).

${ }^{24}$ On the schools founded under the Spanish protectorate by private initiative see Garzón (2008: 313-326).
} 
Las escuelas de Alfonso XIII de Alcázar no son confesionales; en ellas se educan niños musulmanes, cristianos y hebreos, y a horas distintas concurren el sacerdote, el rabino y el fakih para enseñar la religión. En la sección de niños reciben instrucción 232 alumnos, de ellos 159 judíos, 53 cristianos y 20 musulmanes. Al colegio de niñas acuden 150, israelitas en su mayoría. Dirige el centro un maestro español, con un rabino encargado de la instrucción religiosa. La escuela de niñas la preside una profesora española auxiliada por una hebrea.

Las escuelas de Alfonso XIII de Tánger se deben a un donativo de 300.000 pesetas hecho por el marqués de Casa Riera: el terreno donde se construyeron pertenecía a los Reverendos Misioneros y lo cedió el P. Cervera, actual Obispo de Fessea. El Gobierno español sufraga los gastos de entretenimiento de esta institución benemérita, que se inauguró el 23 de Abril de 1913. Están encargados de la enseñanza los PP. Franciscanos de la Misión. Se cursan ella las asignaturas de la primera y segunda enseñanza, y cuenta con una Escuela de Comercio y otra Industrial. Concurren a sus aulas 600 alumnos. El colegio de niñas de Alfonso XIII en Tánger lo dirigen las Madres Terciarias Franciscanas. En el curso de 1917 a 1918 reunió 503 matrículas, de ellas 102 hebreas.

En las escuelas españolas de Arcila se educan 81 alumnos, 39 cristianos y 46 hebreos, y 94 alumnas, 48 cristianas y 46 hebreas. Los estudiantes judíos acuden a las sinagogas, donde un rabino, subvencionado por la Comunidad, les da instrucción talmúdica.

[In Alcazarquivir, a bizarre Spaniard called D. Cristóbal Cala founded the Alfonso XIII schools with very little means, assisted by the then Consul of Spain in Larache, D. Juan V. Zugasti and by D. Hugo Engerez. (...) The Alfonso XIII schools in Alcázar are not denominational; Muslim, Christian and Hebrew children are educated in them and at different times of the day they are visited by priests, rabbis and fakis to teach religion. 232 pupils attend the boys' school, 159 of whom are Jewish, 53 are Christian and 20 are Muslim. The girls' school is attended by 150 pupils, most of whom are Israelites. The headmaster is Spanish and a rabbi is responsible for religious instruction. The headmistress of the girls' school is Spanish, assisted by a Hebrew teacher, also female. The Alfonso XII schools in Tangiers opened thanks to a donation of 300,000 pesetas made by the Marquis of Casa Riera: the ground on which they were built belonged to the Missionary Reverends and was transferred by P. Cervera, now Bishop of Fessea. The Spanish government defrays the maintenance costs of this meritorious institution that opened on 23 April 1913. The Franciscan Fathers of the Mission are responsible for the teaching. Primary and secondary education is offered, and the centre also has a School of Commerce and an Industrial School. 600 pupils fill the classrooms. The Alfonso XIII girls' school in Tangiers is run by the Sisters of the Third Order of St Francis. 503 pupils enrolled in the academic year 1917-1918, of whom 102 were Hebrew. 81 boys attend the Spanish schools in Arcila, of whom 39 are Christian and 46 are Hebrew, and of the 94 girls, 48 are Christian and 46 are Hebrew. Jewish students attend the synagogues, where a rabbi subsidised by the Community, teaches the Talmud.]

(Ortega 1919: 273-274)

Ortega extols the missionaries' teaching in Spanish, yet criticises the lack of initiative on the part of the Spanish state:

La labor de los misioneros españoles en cuanto a enseñanza se refiere, ha sido en Marruecos digna de alabanzas, y si no ha adquirido mayor desarrollo, culpa es de la inactiva desidia de los Gobiernos, más atentos a las exigencias de la política partidista, que a fomentar la influencia de España [...].

[With respect to teaching, the task of Spanish missionaries in Morocco has been worthy of praise, and if it hasn't developed further this is because of the passive indolence of governments, more attentive to the demands of partisan politics than to promoting Spain's influence (...).]

(Ortega 1919: 275)

We should mention here that Spain set up a tripartite educational system in the protectorate, that consisted of three different kinds of schools: the Spanish school, the Spanish-Arab school and the Spanish-Hebrew school, each one meant for a specific population, which ena- 
bled Spain to redefine and outline her policy according to the nationality and denomination of students (González 2012: 117). Following the French model introduced in Algeria and then exported to Morocco, the idea was precisely to create a pro-Spanish elite destined to work in the Spanish administration of the protectorate, so it was imperative that Spanish were the vehicular language for teaching (González 2012: 119). ${ }^{25}$ However, in spite of the fact that the Spanish government acknowledged that teaching in Spanish was "one of the most efficient means of civilisation and penetration we have at our disposal" ${ }^{, 26}$ to ensure the influence of Spanish culture and the colonising ideology, the creation of Spanish teaching centres was slow and was aimed, above all, at primary education. This is why Ortega regrets the nonexistence of schools of higher education, which explains why

[j]óvenes de familias acomodadas perfeccionan su educación en los colegios de España, Inglaterra y Francia. En la Universidad de Granada estudia acualmente derecho un Benarroch de Melilla; en las facultades de nuestro país se han doctorado los médicos Güita, que ejercen su profesión en Madrid, Tetuán y Tánger; en esta última ciudad trabaja brillantemente en su carrera de ingeniero, Benazuli, y en París, en la Embajada de España, desempeña el cargo de médico oficial, el ilustre Doctor Bendelac, tangerino y sefardita.

$[(\mathrm{Y})$ oung people from wealthy families perfect their education in schools in Spain, England and France. At present, a Benarroch from Melilla is reading Law at the University of Granada; the Güita doctors have completed their doctorate studies at colleges in our country and now practice their profession in Madrid, Tetouan and Tangiers; in the latter city Benazuli has a brilliant career as an engineer, and the illustrious Doctor Bendelac, a Sephardic Jew from Tangiers, is an official physician at the Spanish Embassy in Paris.]

(Ortega 1919: 268-267)

However, Ortega warns of the diffusion of French language and culture among Sephardic Jews thanks to the work carried out by the AIU:

La campaña española de 1860 mostró al mundo la sitaución misérrima en que vivían los judíos marroquíes, y la ocupación de Tetuán los redimió en parte de la vil servidumbre en que vegetaban, pero la gran obra de las escuellas de la «Alliance Israelite Universelle» es la que más ha influido en estos últimos tiempos en el progreso intelectual de los hebreos mogrebitas.

[The Spanish campaign of 1860 showed the world the wretched poverty in which Moroccan Jews lived, and to a certain extent the occupation of Tetuoan redeemed them from the despicable servitude in which they vegetated, but in recent years the greatest influence on the intellectual progress of Maghrebi Jews has been the important task of the schools of the "Alliance Israelite Universelle".]

\footnotetext{
${ }^{25}$ With regard to the importance of establishing schools as a means of extending colonial ideology cf. Calvet (2002 [1974]) and Léon (1991).

${ }^{26}$ Communiqué no. 619 from José Marina Vega, High Commissioner of Spain in Morocco to the Minister of State, describing the organisation of the school statistics service of the area. Tetouan: AGA, Sección África. Dirección General de Marruecos y Colonias: Sección de Educación, Box M-324, Report. 7.2. of July 1914, quoted in González González (2012: 119, note 12).
} 
According to Ortega, Spanish plays a secondary role compared to the overwhelming influence of French, as he shows in the example of the Spanish classes at the AIU schools:

\begin{abstract}
En los establecimientos de la Alianza establecidos en Tetuán y Larache, nuestro país costea desde los años 1911 y 1913 respectivamente, un maestro y una maestra que dan lecciones de español una hora al día. Los esfuerzos patrióticos de estos beneméritos profesores no pueden vencer la influencia francesa. Los hebreos se educan y se instruyen en francés, aprendiendo a admirar y a respetar a la gran nación transpirenáica desde sus primeros años. Sin la influencia del hogar donde se habla el castellano, y donde se conserva como algo sagrado el recuerdo de Castilla, pronto desaparecería nuestro idioma de entre los judíos marroquíes.
\end{abstract}

[In the institutions of the Alliance set up in Tetouan and Larache, since the years 1911 and 1913, respectively, our country has been financing two teachers, male and female, to give Spanish lessons one hour a day. The patriotic efforts of these meritorious teachers cannot overcome French influence. The Jews are educated and instructed in French, and learn to admire and respect the great trans-Pyrenean nation from a very early age. Without the influence of the home, where Castilian is spoken and where the memory of Castile is sacredly preserved, our language would soon disappear among Moroccan Jews.]

(Ortega 1919: 267)

Be that as it may, as Ortega observes in the previous quote, the fact that the varieties of Spanish (in its most vernacular form and in its most Hispanicised sense) were present in Sephardic homes favoured its exploitation in other schools of Western influence such as those of the AIU, which used Spanish as the first language of instruction among the Sephardic Jews in northern Morocco, thereby contributing to their re-Hispanicisation. Thus, for instance, in the AIU centres in Tangiers and Tetouan, Spanish was taught for the first two years of schooling, after which it was replaced by French (Benchimol 1901: 131; Leibovici 1984: 62). This model spread to other AIU schools, save for those in the cities of Ceuta, Melilla, Arcila and Xauen where education was exclusively in Spanish hands (Garzón 2008: 314). As all subjects were taught in Spanish, by Spanish teachers (cf. Ortega 1919: 267) and using Spanish text books (Valderrama Martínez 1956: 76), ${ }^{27}$ these Spanish schools played a very important role in the re-Hispanicisation of Haketia.

\title{
5.1.4. Emigration
}

Another reason for the re-Hispanicisation of Haketia is economic, for Spanish speakers found it easier to migrate in search of better financial prospects (Leibovici 1984: 62), first of all to Latin American countries ${ }^{28}$ and subsequently, after the Spanish Civil War, to Spain (Garzón

\footnotetext{
${ }^{27}$ Quoted in Sayahi (2005: 200).

${ }^{28}$ We should not forget, however, that from the late 19th century onwards Brazil was a favourite destination for Moroccan Sephardic Jews, who settled above all in the Amazonian region (Leibovici 1984: 63). Spanish-
} 
2008: 213, 223). In a report he published in the Revue des écoles de l'Alliance Israélite Universelle (1901), Isaac Benchimol, a former teacher at the AIU who in the early 20th century lived in Argentina (cf. Section 5.1.5), highlighted the need to teach Spanish in the AIU schools precisely for these practical reasons (Benchimol 1901: 161), ${ }^{29}$ and this measure was indeed adopted by the AIU, which thereby actively promoted the migration of Jews to Europe and America (Laskier and Bashan 2003: 483). ${ }^{30}$ Indeed, around 1880 emigration to Argentina and Venezuela grew considerably (Benchimol 1901: 128; Leibovici 1984: 63), and in these Latin American countries the presence of Moroccan Sephardic Jews is still great. Even Iquitos, a city in the Peruvian Amazon, received a migration flow in the early 20th century as a result of the boom of the rubber industry, even though the Sephardic community has now disappeared. (Leibovici 1984: 63)

\subsubsection{Diglossia, poliglossia and re-hispanicization of the vernacular}

These political, identity and educational issues had linguistic consequences. The presence and status of the Spanish language led to a diglossic situation ${ }^{31}$ that was beginning to be outlined before 1860 (cf. Section 4). In other words, in the late 19th century Haketia wasn't only characterised diaphasically as the oral language of daily communication while Spanish was reserved for communicative distance, but it also became diastratically characterised as the popular language, the language of the uneducated (Benoliel 2003: 249), as is indeed reflected in Asayag's opinions on the language. Spanish and other Western European languages such as

\footnotetext{
Moroccan Jews also moved to Gibraltar and to the cities of the French Protectorate (Leibovici 1984: 63; Laskier and Bashan 2003: 488).

${ }^{29}$ In northern Morocco, Spanish has continued to be studied for economic and professional reasons, and therefore to favour social mobility. Interestingly, this situation has gradually spread throughout the country, where Spanish is allowed as an official language at civil service examinations to accede to public office (Moustaoui 2005: 146).

${ }^{30}$ Cf. Laskier and Bashan (2003: 483; 489), who say that the schools of the AIU in Tanger and Tetouan also taught, besides French, English and Spanish, essential languages in the coastal areas, in order to facilitate and encourage Jewish emigration to Europe and America.

${ }^{31}$ In the case of the sociolinguistic relationship between Spanish and Judeo-Spanish we use the term diglossia following Ferguson $(1959,1972)$, who suggests the existence of diglossic relations between varieties of the same language, as both the Western and Eastern varieties of Judeo-Spanish derive from Hispanic linguistics. Given the period we are dealing with, Ferguson's definition proves very useful. For the existence of a diglossic relationship, we also bear in mind the following nine points, after Ferguson (1959): (1) distribution of functions; (2) prestige; (3) ongoing literary tradition; (4) conditions for acquiring variety; (5) normativism and normalisation (in the sense noted by Vallverdú [1977]); (6) gradual diglossic relationship between Spanish, considered to be the "high" variety and Haketia, considered to be the "low" variety; (7) differences between the grammar of the two varieties; (8) differences in the phonology of the two varieties; (9) lexical differences between the two varieties. These conditions are quite complementary to the conceptual relationship between communicative immediacy and distance in the Koch and Oesterreicher model (cf. Note 2), also quoted in this article.
} 
French or English were the language of prestige, taught to favour social and economic mobility. Here, however, we find ourselves before a case of polyglossia with an overlapping of two languages (Fassold 1996: 87), in the sense that we have one variety that is considered popular and low (Haketia) in a diglossic relationship with another variety that is considered prestigious (Spanish) and at least one other illustrious Western tongue. ${ }^{32}$ As regards the different linguistic registers of Moroccan Sephardic Jews, Benarroch observes the following:

Los israelitas de habla española de Marruecos disciernen con claridad diversos conceptos idiomáticos:

Llaman español al castellano, de marcado andalucismo, que hablan con características propias; y saben que ciertos términos y expresiones que utilizan no lo son.

Titulan ladino [...] a las traducciones, comunmente orales, de los textos bíblicos y rabínicos y a la lengua en que están expresadas.

Y dicen hakitía a sus voces populares que piensan ser de creación propia, o que no consideran ladino ni castellano moderno, tanto las muy abundantes de raíz arábiga como algunas derivadas del hebreo, así como unos pocos términos de otras lenguas que han tomado carta de naturaleza en el dialecto.

[The Spanish-speaking Israelites in Morocco clearly distinguish several idiomatic concepts: The markedly Andalusian Castilian they speak, that has its own characteristics, they call Spanish; and they know that certain terms and expressions they use don't belong to it. The translations, usually oral, of biblical and rabbinical texts and the language in which they are expressed (...) they term Ladino. And the popular voices they believe are of their own creation, or that they do not consider either Ladino or modern Castilian, they dub Haketia, both those of Arabic origin, that abound, and some of those that derive from Hebrew and a few terms from other languages that have become established in dialect.]

(Benarroch 1970: 267)

So, the Sephardic Jews used Spanish variety very consciously, and according to the degree of communicative closeness, they interspersed expressions taken from Haketia.

Due to this situation of diglossia in which Spanish was used in the formal registers of the language and was associated with socially privileged groups, the vernacular didn't have occasion to take a qualitative leap towards a linguistic elaboration that would enable it to be used in communication fields other than those of the domestic and informal spheres, as had occurred with Eastern Judeo-Spanish. ${ }^{33}$ For these fields of communication, a European language was used directly; in the specific case of Tangiers, Spanish was used, as we deduce from the language of the newspapers published in the town between 1882 and 1934 (cf. Garzón 2008: 402-406; Laskier and Bashan 2003: 484). See Table 5.

\footnotetext{
${ }^{32}$ For a historical and systematic panoramic view of the concepts of diglossia and polyglossia see Kremnitz (2004: 158-165).

${ }^{33}$ On the linguistic and discursive elaboration in Judeo-Spanish from the last third of the 19th century onwards cf. Schmid (2008) and in particular in journalistic genres, cf. Bürki (2006).
} 
Table 5: Newspapers published in Tangiers between 1880 and 1935

\begin{tabular}{|c|c|c|c|}
\hline Name of newspaper & Language of newspaper & Dates of publication & Publishers \\
\hline Al Magreb Al Aqsa & English and then Spanish & $1880-?$ & $\begin{array}{l}\text { Gregorio Trinidad Abrines (Gi- } \\
\text { braltar) }\end{array}$ \\
\hline Le Reveil du Maroc & French & $1880-1899$ & Levi A. Cohen (Tangiers) \\
\hline The Times of Morocco & English & $1884-?$ & Edward Meaking (English) \\
\hline La Africana & Spanish & $1885-1886$ & Eduardo Hanglen (Gibraltar) \\
\hline El Eco Mauritano & Spanish & 1886- 1930 & $\begin{array}{c}\text { Isaac Toledano (Tangiers), Isaac } \\
\text { Laredo (Tangiers), Agustín } \\
\text { Lugaro (Gibraltar) }\end{array}$ \\
\hline Diario de Tánger & Spanish & 1889 & - \\
\hline Le Maroc & French & $?$ & Pinhas Assayag \\
\hline La Crónica & Spanish & $1893-1900$ & $\begin{array}{c}\text { David Shriqui (Tangiers), Isaac } \\
\text { Laredo (Tangiers), Leopoldo } \\
\text { Onetto (?) }\end{array}$ \\
\hline El Porvenir & Spanish & $1900-1830$ & $\begin{array}{l}\text { Francisco Ruiz López (Malaga, } \\
\text { Spain) }\end{array}$ \\
\hline $\begin{array}{l}\text { La Duda del Progreso } \\
\text { Marroquí }\end{array}$ & Spanish & $1909-1909$ & David Shiriqui (Tangiers) \\
\hline Tangier Times & English & 1920-? & Monti Corcos (Mogador) \\
\hline $\begin{array}{l}\text { El Heraldo de } \\
\text { Marruecos }\end{array}$ & Spanish & $1925-1932$ & $\begin{array}{c}\text { Manuel Ortega (Jerez de La } \\
\text { Frontera, Spain) }\end{array}$ \\
\hline El Magrebí & Spanish & 1934 & $\begin{array}{c}\text { Alberto España (Ronda, Spain), } \\
\text { Yosef Hassán (Tetouan) }\end{array}$ \\
\hline
\end{tabular}

Indeed, of the thirteen newspapers listed, if we take away those published in English both by the Sephardic Jews in Gibraltar and by the British (three), those published by Sephardic Jews in French (two) and those run by Spanish journalists (two), we see that seven appeared in Spanish under the encouragement and direction of Sephardic Jews. If we look at the language of the ethnic press destined for the Jews in the region (cf. Garzón 2008: 407-410; Laskier and Bashan 2003: 484), the situation is the same: of the eleven periodical publications, three were published in Arabic in Hebrew script (Kol Israel, 1891; Le Mebasser Tob, 1894-1895; El Horria, 1915-1917), one in French (La Liberté, 1915-1922), one in Arabic and French (Le Moghrabi, 1904) and the remaining seven in Spanish in Latin script and not, as is characteristic in Jewish languages, in Hebrew script (cf. Section 2) (El Eco Israelita, 1915; 
Renacimiento de Israel, 1924-1933; Kol Hanobar. Órgano de la Unión Universal de Juventudes Judias, 1927; Adelante, 1929-1931/1932?; Crisol Judio, 1931; Or/Luz, 1956).

This linguistic situation remained unchanged in the case of another genre of the communicative distance: the excerpts from the reports of the Yagdil Torá society in Tetouan for the years 1913 to 1920 (also published by Garzón [2008: 503-513]) are written in Spanish in Latin script, and contain only a few Hebraisms relative to communal organisation. Examples are as follows: melamed, Perachá ${ }^{34}$ 'extract of Sabbatical interpretation of the Pentateuch', dinim 'laws or justice', Gemara 'rabbinical comments on the Mishnah', yeshiva' 'rabbinical school', misva 'prescription, precept', hajamim 'sages', Tefillin 'phylacteries', Shevat 'the eleventh month in the Jewish calendar, that coincides with January or February in the Christian calendar', Elul 'the last month in the Jewish calendar, that coincides with August or September in the Christian calendar'. As revealed by these texts, in the 20th century Sephardic Jews in Morocco wrote in Spanish in Latin script and used normative spelling conventions; according to Bentolila (2008: 173), this tendency began to appear in the late nineteenth century and only when there was an intention to bring a Jewish nuance to their written compositions, especially on the part of rabbis, did they resort to the Hebrew script. ${ }^{35}$

However, it was not only Spanish that became the written language for formal registers and the educated classes, but Haketia itself that began to adopt Spanish characteristics. On this subject, Bendelac affirms (1987: 62) that sometimes the Hispanicisation of Haketia went so far that the borders between Haketia influenced by Spanish and Spanish influenced by Haketia were blurred.

As early as 1945 Bénichous had warned of the aspects of Hispanicism that began to appear in Haketia, and in 1960 he turned to them again in his notes on the Cancionero del Norte de Marruecos published by Arcadio Larrea Palacín (1954) and the collection of Endechas judeoespañolas edited by Manuel Alvar (1953). Among the phonological features pointed out by Bénichou (1960), besides the aforementioned replacement of the prepalatal / $/$ and $/ 3 /$ with the Spanish /x/, mention should be made of the vacillations between /s/ and /z/ (of the sort [roza] vs. [rosa]) (cf. Note 4), that seem to prove a regression of the sonorous /z/ in favour of the non-sonorous /s/; the occasional infiltration of a Spanish interdental consonant $/ \theta /$ (nonexistent in Judeo-Spanish), alternating with the vernacular non-sonorous pre-dorsal consonant

\footnotetext{
${ }^{34}$ We have respected the original spelling.

${ }^{35}$ Nonetheless, we also come across texts written in Solitreo, as is the case of the Libro de actas de la Junta selecta de la comunidad hebrea de Tanger desde heshvan 6621 hasta 29 iyar 5635 (cf. Note 13).
} 
(of the sort [s'irjo] vs. [ $\theta$ 'irjo]). Likewise, non-literary texts written in Haketia published later reveal the progress of Spanish. Such is the case of the 298 proverbs in Haketia compiled and annotated over a number of years by Anita Lévy, a native of Tetouan who emigrated to Canada, and studied by Bentolila (2006). ${ }^{36}$ The Hispanicising elements mentioned by Bentolila include the replacement of Hak. ande by Sp. donde, of Hak. mazzal by Sp. suerte, of Hak. munchas by Sp. muchas and of Hak. escuridad by Sp. oscuridad. At the phonetic/phonological level, besides the well-known velarisation of prepalatal consonants, Bentolila notes the loss of the prosthetic g- in words such as Hak. güerfano in favour of Sp. huérfano, and the loss of the velar $g$ - in Hak. güeno as opposed to Sp. bueno.

\subsection{The Alliance Israélite Universelle and French}

The AIU was established in 1860 by enlightened French Jews with the intention of fighting for the political rights of the Jews in the Ottoman Empire and North Africa, and of emancipating them, in keeping with the proclamation of citizens' rights by the French Revolution. ${ }^{37}$ According to the ideology of the enlightened Jews, this objective could only be fully achieved if these Jewish communities were 'regenerated' by modernisation and Western education, and the superstitions and prejudices that prevented their progress were thus destroyed. With this in mind, a vast network of schools was set up in which education was based on a modern curriculum and where the language of transmission was French. In this way, the AIU schools acted as a means for the diffusion of French language and culture in the East and in North Africa.

The importance of North African Jews in the AIU plans of Westernisation and modernisation is reflected in the fact that the first of its schools opened in Tetouan in 1862. Between the years 1862 and 1935 the AIU opened 48 primary schools in Morocco, both boys' schools and girls' schools; ten of the latter were founded in the region of the Spanish protectorate, which included the city of Tangiers. ${ }^{38}$

\footnotetext{
${ }^{36}$ The Haketian texts published by Benabú (2011), despite the fact that the author highlights precisely the characteristics of the Western Judeo-Spanish variety, also reveal Hispanicising trends, such as the alternation between velar and palatal fricatives, the presence of [fwe] instead of [fe], of diphthonged forms in rhizotonic verbs ([kjero]) as opposed to non-diphthonged forms ([kero]) or the presence of Hispanicisms such as dios 'God' for dio.

${ }^{37}$ There are countless studies on the Alliance Israélite Universelle. Our contribution is based on the following works: Kaspi (2010), Rodrigue (2003), Laskier (1994) and Laskier (1982).

${ }^{38}$ Rodrigue (2003: 18-19) presents an exhaustive list of schools founded by the AIU in Morocco.
} 
In northern Morocco, particularly in the cities of Tetouan and Tangiers, French certainly exerted a great influence that contributed to the Westernisation of Sephardic Jews, which entailed the disappearance of the vernacular. As noted by Garzón (2008: 236), knowledge of Western languages created a social barrier between those who spoke Haketia and those who were fluent in Spanish or French, and the apparent ignorance of the dialect was even considered in good taste. In fact, many Sephardic intellectuals from Tangiers and Tetouan had a perfect command of Spanish and French. Such were the cases of Pinhas Asayag, who set up the short-lived Tangerine newspaper Le Maroc (cf. Section 5.1.5.), and of Isaac Benchimol, for many years a school teacher at the AIU in Tetouan before emigrating to Argentina. In this sense, what Laskier (1994: 31) propounded in the 1950s - "both Spanish and French became widespread among [the majority of urban Jewish youth] in the International Zone of Tangier and Spanish Morocco" - had already been true for a number of years.

Yet, even though in the early 20th century Hispanophiles had a different impression (cf. Section 5. 1. 3.), the linguistic impact of the AIU schools in Morocco (despite being the area where they remained in operation the longest) wasn't as great as it was among the Sephardic Jews in the Ottoman Empire. Thanks to the all-present influence of the AIU, this variety of Judeo-Spanish was re-Romanised through French. In the specific case of the Sephardic communities on the northern coast of Morocco, the most important reason for this was precisely the continuous presence of Spanish, note worthy enduring and notorious after 1860. To quote Alslanov (2008: 220), "the prolonged contact between Haketia and Spanish protected it from the intrusion of French".

\section{New diaspora after the protectorate}

Over and above the process of Hispanicisation undergone by Haketia, this vernacular practically disappeared from the land in which it had emerged as a result of the intense emigration of Moroccan Sephardic communities when the protectorate period came to an end.

One of the reasons that led to the exit of the Sephardic community from Morocco was the creation of the State of Israel in 1948, which triggered the massive emigration of Jews from North Africa to the Hebrew State (Abitol 2010: 389). The Jews of Spanish descent, albeit to a lesser degree than those from the French area (Laskier and Bashar 2003: 498), ${ }^{39}$ went to Israel; it is estimated that between the years 1954 and 1956, the date of the independence of Mo-

\footnotetext{
${ }^{39}$ On the impact of Sionism in the French protectorate and the migration of Jews from this area to Israel cf. Laskier (1994: 84-113).
} 
rocco, for instance, between 2000 and 3000 Jews from the Spanish-Moroccan group moved to Israel (Garzón 2008: 188).

One of the motives that greatly stimulated migration was the birth of the Moroccan nationalist movement (1944) that would lead to the independence of the country (1956) and the consequent loss of the status of international protection of the city of Tangiers. Indeed, the Jews feared that Morocco's Arabist policies would entail the end of its openness to the West, a fear that was aggravated in 1958 with Morocco's accession to the Arab League (Abitol 2010: 396). For the Sephardic Jews, the nationalisation of the AIU schools in Morocco in 1962 (Abitol 2010: 397) was a clear example of this loss of Western influence, as the institution was a symbol of the modernisation of Moroccan Judaism. Table 6 shows the decrease in the Jewish population of Tangiers and Tetouan between the years 1936 and 1963.

Table 6: Figures of the Jewish population in the cities of Tangiers and Tetouan between 1936 and 1963

\begin{tabular}{|l|c|c|c|c|}
\hline \multicolumn{1}{|c|}{ City } & $\mathbf{1 9 3 6}$ & $\mathbf{1 9 5 1}$ & $\mathbf{1 9 6 1}$ & $\mathbf{1 9 6 3}$ \\
\hline Tangiers & 10,000 & 10,000 & 6,246 & 5,402 \\
\hline Tetouan & 6,000 & 6,000 & 5,674 & 5,202 \\
\hline
\end{tabular}

The fear grew after the Seven Years' War of 1967 that unleashed an anti-Semitic wave in Morocco. According to Garzón (2008: 193), between 1967 and 1973 so many members of the Sephardic community left the northern region of the country that barely any Jews remained. During that period precisely, Spain became the main destination of Sephardic Jews from northern Morocco; on their last diaspora they joined the Sephardic communities of Melilla, Ceuta, Seville, Barcelona and Madrid (Garzón 2008: 223). Venezuela, Argentina and Brazil - albeit the latter to a lesser extent than in the 19th century - continued to be special settlements for Spanish-Moroccan Jews. French-speaking countries provided a minor destination: a small group of Tangerine descent moved to France (Garzón 2008: 223); others, also from Tangiers, settled in the city of Montreal, although most Sephardic Jews established themselves in the English-speaking town of Toronto (Garzón 2008: 222). As Laskier and Bashar have pointed out (2003: 484), due to contact with Europeans, the Jews in the coastal cities of northern Morocco gradually lost their traditional lifestyle and became Westernised; to remain in Morocco under an Islamic regime was no longer compatible with their new situation. 
Following the last diaspora, generated by the creation of the State of Israel, the loss of status of the protectorates and the independence of Morocco, the history of the Spanish-Jewish community in northern Morocco came to an end.

\section{Haketia today}

In recent years, Haketia has witnessed the development of a movement for its preservation as a part of the cultural heritage of Sephardic Jews in Morocco and their social memory outside the land in which it was born and withered (cf. Benabu 2011: 38; Bengio 2012: 233; Garzón 2006: 194-195). Several dictionaries have been published, such as those by Alegría Bendayán de Bendelac (1995) and Isaac Benharroch (2004); recordings have been made, such as those that accompany the book La vida en haketía. Para que no se pierda (2012) by Solly Lévy and Esther Aflalo Cohen; another book of this sort is Los Nuestros. Sejiná, Letuarios, Jaquetia y Fraja. Un retrato de los sefardies del norte de Marruecos a través de sus recuerdos y de su lengua (1860-1984), also published by Alegría Bendayán de Bendelac (1987). Even the Tangerine writer Solly Lévy based in Quebec published his book Yahasrá, escenas haquetiescas (1992) in Haketia, a vernacular that is actually based on oral tradition.

However, as is also the case with Judezmo (Schmid 2007: 30), ${ }^{40}$ in view of the fact that Moroccan Sephardic Jews are scattered around different parts of the world and have a disparate knowledge of Haketia, which is not in fact their language of daily communication, "new networks of 'speakers' not geographically located" (Schmid 2007: 30) have been formed in the virtual spaces of the Internet. One example of this is the "Voces de Haquetía" website ${ }^{41}$ that disseminates the history, oral literature, photos, music and cuisine of the Sephardic Jews of Morocco. In the case of Haketia, by providing it with a graphic system in Latin letters for its script to be disseminated on the Internet, the new electronic networks do not create only spaces for "speakers" 42 but for "writers" as well. Indeed, "Voces de Haquetía" presents a

\footnotetext{
${ }^{40}$ The strong presence of Judezmo on the Internet is unquestionable, with countless websites providing information on Ladino and its preservation, publishing short stories, proverbs, anecdotes and cookery recipes, usually in the writing system suggested by the Autoridad Nacional del Ladino (http://www.akiyerushalayim.co.il/index.htm).

${ }^{41}$ Cf. http://www.vocesdehaketia.com/index.html (accessed 2 August 2014).

${ }^{42}$ The electronic magazine Aki Yerushalayim also includes a section devoted to Haketia, "El kantoniko de la haketia" (cf. Note 13). On the contents of this section, see Alexander (2007: 97-105).
} 
script "that is being elaborated by a team of Haketia lovers", accompanied by an example of its pronunciation. ${ }^{43}$

\section{Conclusions and possible future lines of research}

This article has examined the gradual disappearance of Haketia as the language of the Sephardic Jews in northern Morocco from a diachronic and external perspective. In this section we shall interpret its disappearance from a glottopolitcal angle, turning to the theoretical proposals of Gal and Irvine $(2000,2006)$. We start from the fact that all spaces become places insofar as they are geographical divisions experienced by the human groups inhabiting them, thanks to the sociocultural and political practices carried out within their boundaries (Casey 1996: 14-52; Gal 2010: 46-47). It is not only that these practices are expressed through language, or discourse (Casey 1996: 19), but that language itself is the object of a meta-discourse that approves the varieties perceived in given places as correct and suitable for certain "high" discursive practices, whereas others are either reserved for discursive practices in family settings or are branded as "low" (Gal 2010: 39-40).

In the case of Haketia one key aspect that distinguishes the tongue from the other branch of Judeo-Spanish-Judezmo - is the fact that contact with Spain and Spanish was never lost. Geographic proximity thus proved to be a decisive circumstance, and explains why at the linguistic level Haketia had begun to show signs of Hispanicisation in the phonetic/phonological field in texts of communicative distance as early as the late 18th century. As noted by Gal (2010: 40), contrary to what could be expected, "differentiation arises from the juxtaposition of contrastively valued linguistic varieties", consequently "linguistic change is best understood as a consequence of intimate contact among speakers rather than distance".

Affective and identity ties with Spain were strengthened after the Spanish occupation of 1860; according to testimonies of the period, Sephardic Jews saw the Spanish invaders as "liberating" allies, rescuing the idea of a common origin in order to confront Muslims. The period of the protectorate entailed no change in this sense, deepening and strengthening the relations established between Spaniards and Sephardic Jews during the invasion of 1860. At the level of language, this meant the gradual and unstoppable adoption of Spanish to the detriment of Haketia, on the one hand because it was the language of the colonisers and the rul-

\footnotetext{
${ }^{43}$ Cf. http://www.vocesdehaketia.com/haketia/grafia.htm (accessed 2 August 2014).
} 
ing political class to whom the Sephardic Jews felt connected, seeking refuge in the idea of a common past. In this sense, and turning to the semiotic processes of iconisation, fractual recursivity and erasure (Irvine and Gal 2000), Spanish doesn't just emerge as an icon, insofar as it represents the Hispanic identity of Sephardic Jews, but it also seems to suggest a process of recursivity, for Spanish, as the language of the new political force, is opposed to Arabic, the language of the ancien régime. Spanish, on the other hand, is gaining ground according to the prevailing linguistic ideology of the age, given that Spanish was considered a modern language of culture-like French and English - and therefore susceptible of being used in all communicative situations and in all registers of modern life. Furthermore, this facilitated emigration in search of economic progress, while Haketia was no more than a corrupted Spanish, a patois, as pointed out by Cohen and Asayag in 1903 and 1904 respectively. So we could well say that among Sephardic Jews, Spanish began to serve as a Dachsprache, or roofing language, and Haketia assumed two different positions according to the level at which we are looking: on the diastratic level, it began to be associated with the uneducated working classes, and therefore occupied the lowest position on the Dachsprache scale; on the diaphasic level, the number of words and expressions from Haketia grew in proportion to communicative inmediacy between interlocutors and it was used as a familiar register. The development of Spanish and French literacy skills in the Spanish and French schools of the AIU was certainly decisive in the established linguistic hierarchy.

The general acceptance of Spanish as the language of education and culture didn't sanction the linguistic and discursive elaboration of Haketia in modern written genres of communicative distance such as journalism. As has been explained, most of the press was published in Spanish in Latin script, although most publicists were Sephardic Jews. In other words, we could say that the practice of Haketia was erased in the mass media and in what were perceived to be highly formal registers. In this way, Spanish "covered" Haketia, on which it was superimposed, and therefore envisaged as being "above" it. The practice of Haketia was not perceived as simply different, or typical of different geographical regions of a given ethnocultural group. It is perceived and judged by the people of the same ethnocultural group to be "lower", and therefore worse (cf. Gal 2010: 38).

This situation also contrasts with that of Eastern Sephardic Jews in the Ottoman Empire, where there was a linguistic and discursive development in Judeo-Spanish and in Hebrew 
script. Perhaps for this very reason we have no evidence of supporters of the adoption of Haketia as a language of culture for Moroccan Sephardic Jews, as was the case in the East. ${ }^{44}$

Finally, emigration helped further weaken Haketia as a vehicle of communication. Although the migratory movements of Moroccan Sephardic Jews in search of better opportunities were constant since the nineteenth century (especially to America), the end of the protectorate, the creation of the State of Israel and the independence of Morocco, and the consequent establishment of a Muslin nation-state, triggered the massive exodus of Moroccan Sephardic Jews. As a result of their being dispersed in different countries with their own vehicular tongues, Haketia had even fewer possibilities of being used outside of cultural expressions such as songs and proverbs. To this we should add, as we have pointed out, that knowledge of the language must have been very irregular and that, for the same reasons, the number of its speakers is now impossible to determine. Undoubtedly, due to the very development of the language, it is restricted to fields related to the customs and life of the past in Morocco. Perhaps for this reason precisely, outside the land where it appeared and in the countries of the new diaspora, Haketia has become an icon of Moroccan Sephardic culture. Given the dissemination of North African Sephardic Jews, spatial and temporal differences aside, North African Sephardic Jew communities with more or less knowledge of Haketia now come together in the boundless world of cyberspace.

Opening research windows to the future, in glottopolitical and ideological terms, there is scope for deeper and more extensive study of the connections between Haketia, Spanish and Arabic as established among the Sephardic Jews in northern Morocco. Outside of this geographical area and as a result of the new diasporas, I find the idea of examining the process of iconisation of Haketia as an identifying element very promising. What is the discourse created around this tongue? What are its salient features and, in terms of recursivity, which of its features are distinct from Spanish?

\section{References}

Abitol, Michel. 1993. Judíos ibéricos, musulmanes y cristianos tras la expulsión: el caso norteafricano. In Henry Méchoulan (dir.), Los judíos de España. Historia de una diáspora. 1492-1992, 486-489. Madrid: Editorial Trotta.

\footnotetext{
${ }^{44}$ The figure of Sam Lévy (Šemuel Sa'adí Halevy), Sephardic publicist and intellectual from Salonica, was prominent in the debates held between the last decade of the 19th century and the 1930s regarding the tongue that Eastern Sephardic Jews should use as a general vehicle of communication. Lévy defended the adoption of Judeo-Spanish as the language of culture of Eastern Sephardic Jews. Cf. in this respect Bürki (2013) and Romero (2010).
} 
Abitol, Michel. 2010. Décolonisation et indépendences: l'impact en Afrique du Nord. In André Kaspi (dir.), Histoire de l'Alliance israélite universelle. De 1860 à nos jours, 388404. Paris: Armand Collin.

Alarcón, Pedro Antonio. 1860. Diario de un testigo de la guerra de África. Madrid: $\begin{array}{lllll}\text { Imprenta } & \text { L } & \text { Librería } & \text { de Roig. }\end{array}$ http://www.bibliotecavirtualdeandalucia.es/catalogo/consulta/resultados_busqueda.cm d?id=338\&materia_numcontrol=\&autor_numcontrol=\&posicion=10\&forma=ficha (accesed 12.07.2014)

Alexander, Tamar. 2007. 'El Kantoniko de la Haketia' de Aki Yerushalayim. In Pablo Martín Asuero \& Karen Gerson Sarhon (eds.), Ayer y hoy de la prensa en judeoespañol, 97105, Istanbul: Isis.

Aslanov, Cyril. 2008. La haquetía entre hispanidad y aloglotismo: divergencia y convergencia. In Tamar Alexander \& Yaakov Bentolila (eds.), La cultura JudeoEspañola del Norte de Marruecos [Special Issue]. El Prezente. Studies in Sephardic Culture 2, 209-222.

Assis, Yon Tov. 2008. The Jews of the Maghreb and Sepharad: A Case Study of InterCommunal Cultural Relations through the Ages. In Tamar Alexander \& Yaakov Bentolila (eds.), La cultura Judeo-Española del Norte de Marruecos [Special Issue]. El Prezente. Studies in Sephardic Culture 2, 11-30.

Ayoun, Richard. 1993. Argelia y Tunez: de los siglos XIII al XX. In Henry Méchoulan (dir.), Los judios de España. Historia de una diáspora. 1492-1992, 475-485. Madrid: Editorial Trotta.

Benabu, Isaac. 2011. Western Judeo-Spanish (Hakitía): Tracing Speech Through Narrative, European Judaism 44 (1) (Spring, 2011), 36-50.

Benady, Tito. 1993. Las comunidades del Norte de Marruecos. In Henry Méchoulan (dir.), Los judíos de España. Historia de una diáspora. 1492-1992, 507-514. Madrid: Editorial Trotta.

Benarroch, Carlos. 1970. Ojeada sobre el judeoespañol de Marruecos. In Iacob M. Hassán (ed.), Actas del Primer Simposio de Estudios Sefardíes. Madrid: CSIC, 263-275.

Benchimol, Isaac.1901. La langue espagnol au Maroc. Revue des écoles de l'Alliance Israélite Universelle 2, 126-133.

Bendayan de Bendelac, Alegría. 1987. Los Nuestros. Sejiná, Letuarios, Jaquetía y Fraja. Un retrato de los sefardies del norte de Marruecos a través de sus recuerdos y de su lengua (1860-1984). New York-Berna-Frankfurt am Main-Paris: Peter Lang.

Bendayan de Bendelac, Alegría. 1995. Diccionario del judeoespañol de los sefardíes del norte de Marruecos. Caracas: Centro de Estudios Sefardíes de Caracas.

Bengio, Abraham. 2012. L'Espagne des trois cultures. La hakétia, judéo-espagnol nordmarocain. Horizons Maghrébins 67, 229-235.

Benharroch, Isaac. 2004. Diccionario de Haquetía: guía esencial del dialecto de los judíos del norte de Marruecos. Caracas: Asociación Israelita de Venezuela.

Bénichou, Paul. 1945. Observaciones sobre el judeo-español de Marruecos. Revista de Filología Hispánica 7, 209-258. 
Bénichou, Paul. 1960. Notas sobre el judeo-español de Marruecos en 1950. Nueva Revista de Filología Hispánica 14, 307-312.

Benoliel, José. 1926. Dialecto judeo-hispano-marroquí o Hakitía. Boletín de la Real Academia de la Lengua Española 13, 209-233, 342-363, 507-538.

Benoliel, José. 1927. Dialecto judeo-hispano-marroquí o Hakitía. Boletín de la Real Academia de la Lengua Española 14, 137-168; 196-234; 357-373; 566-580.

Benoliel, José. 1928. Dialecto judeo-hispano-marroquí o Hakitía. Boletín de la Real Academia de la Lengua Española 15, 47-61.

Benoliel, José. 1977 [1926; 1927; 1928; 1952]. Dialecto judeo-hispano-marroquí o Hakitía. Barcelona: Amaller.

Bentolila, Yaakov. 2003. Le processus d'hispanisation de la hakétia à la lumière de quelque sources litteraires. In Frank Álvarez-Péreyre \& Jean Baumgarten (dirs.), Linguistique des langues juives et linguistique générale. Paris: CNRS, 247-266.

Bentolila, Yaakov. 2008. La lengua común (coiné) judeo-española entre el Este y el Oeste. In Tamar Alexander \& Yaakov Bentolila (eds.), La cultura Judeo-Española del Norte de Marruecos [Special Issue]. El Prezente. Studies in Sephardic Culture 2, 159-176.

Bunis, David M. 1993. El idioma de los sefardíes: un panorama histórico. In Moreset Sefarad: El legado de Sefarad. Jerusalem: Magnes / Hebrew University of Jerusalem, vol. II, 414-437.

Bunis, David M. 2008. The Differential Impact of Arabic on Haketía and Turkish on Judezmo. In Tamar Alexander \& Yaakov Bentolila (eds.), La cultura Judeo-Española del Norte de Marruecos [Special Issue]. El Prezente. Studies in Sephardic Culture 2, 177-207.

Bürki, Yvette. 2006. El discurso periodístico de la prensa judeoespañola del siglo XIX. In Yvette Bürki / Beatrice Schmid / Armin Schwegler (eds.): Una lengua en la diáspora: el judeoespañol de Oriente [Thematic Issue]. Revista de Lingüística Iberoamericana IV/2 (8), 53-76.

Bürki, Yvette. 2013. The status of Judeo-Spanish in the Ottoman Empire. In José del Valle (ed.), A Political History of Spanish. The Making of a Language. Cambridge: Cambridge University Press, 691-722.

Bürki, Yvette, Schmid, Beatrice \& Schwegler, Armin. 2006. Introducción. Revista de Lingüística Iberoamericana 4.2 (8), 7-11.

Calvet, Louis. 2002 [1974]. Linguistique et colonialism. Petit traité de glottophagie. Paris: Payot.

Casey, Edward. 1996. How to get from space to place in a fairly short stretch of time: Phenomenological prolegomena. In Steve Feld / Keith Basso (eds.), Sense of place. Santa Fe (New Mexico): School of American Research Press, 13-52.

Cohen Aflalo, Esther / Lévy Solly. 2012. La Vida en Haketía. Para que no se pierda Certeza / Riopiedras-Centro Sefarad Israel-Caminos de Sefarad.

Cohen, David. 1985. The Arabic Dialects Spoken by North African Jews. In Joshua Fishman (ed.), Readings in the Sociology of Jewish Languages. London: Leiden, 240-260.

Díaz-Mas, Paloma. 2013. Musulmanes y judíos en la literatura africanista española: tres testimonios de principios del siglo XX. Lusitania Sacra 27, 127-152. 
Elspass, Stephan. 2012. The use of private letters and diaries in sociolinguistic investigation. In Juan Manuel Hernández Campoy / Juan Camilo Conde Silvestre (eds.), Handbook of Historical Sociolinguistics. Oxford: Wiley-Blackwell, 157-169.

Fasold, Ralph. 1996 (1984). The sociolinguistics of language. Cambridge [etc.]: Basil Blackwell.

Ferguson, Charles A. 1959. Diglossia. Word 15, 324-340.

Fergusson, Charles A. 1972. Diglossia. Pier Paoli Giglioli (eds.), Language and Context. Harmondsworth: Middleessex, 232-251.

Fishmann, Joshua. 1967. Bilingualism with and without diglosia, diglosia with and without bilingualism, Journal of Social Issues 2/XXIII, 29-38.

Fishmann, Joshua. 1972. Advances in the sociology of languages. The Hague: Mouton, vol. 2.

Gal, Susan. 2010. Language and political space. In Peter Auer / Jürgen Erich Schmitt (eds.)

Language and space. An international handbook of linguistic variation. Vol. 1. Auer, Berlin / New York: Mouton de Gruyter, 33-49.

García Moreno, Aitor. 2004. Relatos del pueblo ladinán (me`am lo`ez de éxodo). Madrid: Consejo Superior de Investigaciones Científicas.

Garzón Serfaty, Moisés. 2006. La jaquetía. Sefárdica 16, pp. 185-195.

Garzón, Jacobo Israel. 2008. Los judíos hispano-marroquíes (1492-1973). Madrid: Hebraica Ediciones.

González García, Isidro. 1987. España y los judíos del Norte de África. Aportes. Revista de Historia Contemporánea [hasta 1987: Revista de Historia del siglo XIX] 7, 3-17.

González González, Irene. 2012. Escuelas, niños y maestros: la educación en el Protectorado español en Marruecos. Awraq. Revista de análisis sobre el mundo árabe e islámico contemporáneo 5-6, 117-132.

Hassán, Yacob M. 1968. De los restos dejados por el judeoespañol en el español de judíos del Norte de África. In Congreso Internacional de Lingüística y Filología Románica. Madrid: C.S.I.C / Patronato Menéndez y Pelayo, vol. IV, 2127-2140.

Irvine, Judith / Gal Susan. 2000. Language ideology and linguistic differentiation. In Paul V. Kroskrity (ed.), Regiomes of language. Ideologies, polities and identities. Oxford: James Currey, 35-84.

Kaspi, André (dir.). 2010. Histoire de l'Alliance Israélite Universelle de 1860 à nos jours. Paris: Armand Colin.

Kremnitz, Georg. 2004. Diglossie - Polyglossie / Diglossia - Polyglossia. In Ulrich Ammon / Norbert Dittmar / Klaus J. Mattheier \& Peter Trudgill (eds.), Sociolinguistics / Soziolinguistik. An International Handbook of the Science of Language and Society / Ein internationales Handbuch zur Wissenschaft von Sprache und Gesellschaft. New York: Mouton de Gruyter, vol. 1, 158-165.

Laskier, Michael M. 1982. The Alliance Israelite Universelle and the Struggle for the Recognition within Moroccan Jewish Society: 1862-1912. In Issachar Ben-Ami (ed.), The Sephardi and Oriental Jewish Heritage. Studies. Jerusalem: The Magness Press-The Hebrew University of Jerusalem, 191-212.

Laskier, Michael M. 1994. Israel and the Maghreb. From Statehood to Oslo. Florida: University Press of Florida. 
Laskier, Michael M. / Bashan, Eliezer. 2003. Morocco. In Reeva Spector Simon, Michael Menachem Laskier \& Sara Reguer (eds.), The Jews oft he Middle East and North Africa in Modern Times. New York: Columbia University Press, 471-504.

Leibovici, Sarah. 1984. Aproximación hispano-judía en el Marruecos ochochentista (Tetuán, 1862-1896). Anales de Historia Contemporánea 3, 59-67.

Léon, Antoine. 1991. Colonisation. Ensegnaiment et éducation. Étude historique et comparative. Paris: L'Harmattan

Lévy, Solly. 1992. Yahasrá. Montréal. Institut de la culture sépharade de la Communauté Sépharade du Québec.

López García, Bernabé. 2012. Los españoles de Tánger. Awraq. Revista de análisis sobre el mundo árabe e islámico contemporáneo 5-6, 1-39.

Martínez Ruiz, Juan. 1992. Lenguas en contacto: judeoespañol y árabe marroquí. Interferencias léxicas, fonéticas y sintácticas. In Actas del Cuarto Congreso Internacional de Hispanistas. Salamanca: Asociación Internacional de Hispanistas / Consejo General de Castilla y León-Universidad de Salamanca, vol. II, 237-249.

Menéu, Pascual.1890. Dialecto hispánico-hebraico en el imperio de Marruecos. El Archivo 4 (4), 83-86.

Meyuhas Ginio, Alisa. 2008. El encuentro del senador español Dr. Ángel Pulido Fernández con los judíos del Norte de Marruecos. In Tamar Alexander \& Yaakov Bentolila (eds.), La cultura Judeo-Española del Norte de Marruecos [Special Issue]. El Prezente. Studies in Sephardic Culture 2, 111-125

Moustaoui Srhir, Adil. 2005. La diglosia y la poliglosia como procesos de subordinación lingüística: estudio del caso de Marruecos, Estudios de dialectología norteafricana y andalusí 9, 139-149.

Ortega, Manuel. 1919. Los hebreos en Marruecos. Madrid: Ediciones Nuestra Raza.

Pimienta, Gladys. 1993. Espagnol et Haketía à travers les chanson judéo-espagnoles du Maroc. Yod 33-34, 133-139.

Pimienta, Gladys \& Pimienta, Sydney Salomón. 2010. Libro de actas de la Junta Selecta de la Comunidad Hebrea de Tánger, 1860-1883 : (nacimiento y desarrollo de una comunidad organizada). Paris / Jerusalem: JEM / EREZ.

Pulido Fernández, Ángel. 1904 Los israelitas españoles y el idioma castellano. Madrid, Sucesores de Rivadeneyra.

Pulido Fernández, Ángel. 1905. Españoles sin patria y la raza sefardí. Madrid: E. Teodoro.

Rodrigue, Aaron. 2003. Jews and Muslims. Images of Sephardi and Eastern Jewries in Modern Times. Seattle / London: University of Washington Press.

Romero, Elena. 2010. La polémica sobre el judeoespañol en la prensa sobre sefardí del imperio otomano: materiales para su estudio. In, Paloma Díaz-Más / María Sánchez Pérez (eds.), Los sefardíes ante los retos del mundo contemporáneo. Identidades y mentalidades. Madrid: CSIC, 55-64.

Sayahi, Lofti. 2005. El español en el norte de Marruecos. Historia y análisis. Hispanic Research Journal 6, 195-207.

Schmid, Beatrice. 2007. De Salónica a Ladinokomunita. El judeoespañol desde los umbrales del siglo XX hasta la actualidad. In Germà Colón Domènech \& Lluís Gimeno Betí 
(eds.), Ecologia lingüística i desaparició de llengües. Castelló de la Plana: Universitat Jaume I, 29-33

Schmid, Beatrice. 2008. La lengua sefardí en su plenitud. In Elena Romero (ed.), Sefardíes: Literatura y lengua de una nación dispersa. Cuenca: Universidad de Castilla-La Mancha, 51-79.

Simon, Rachel. 2003. Education. In Reeva Spector Simon, Michael Menachem Laskier \& Sara Reguer (eds.), The Jews oft he Middle East and North Africa in Modern Times. New York: Columbia University Press, 142-164.

Vallverdú, Francesc. 1977. La normalizatió del català, Treballs de Sociolinguistica Catalana $1,147-155$.

Vilar, Juan Bautista. 2012 [2006]. La España del exilio. Las emigraciones políticas españolas en los siglos XIX y XX. Madrid: Síntesis.

Wagner, Max Leopold. 1931. Zum Judenspanischen von Marokko. Volkstum und Kultur der Romanen 4, 221-245.

Zafrani, Haïm. 1993. Las comunidades judías de origen ibérico de Marruecos, desde 1492 hasta nuestros días. In Henry Méchoulan (dir.), Los judíos de España. Historia de una diáspora. 1492-1992, 490-506. Madrid: Editorial Trotta. 